\title{
THE LARVAL MIDGUT OF Anticarsia gemmatalis (HÜBNER) (LEPIDOPTERA: NOCTUIDAE): LIGHT AND ELECTRON MICROSCOPY STUDIES OF THE EPITHELIAL CELLS
}

\author{
LEVY, S. M., ${ }^{1}$ FALLEIROS, A. M. F., ${ }^{2}$ GREGÓRIO, E. A., ${ }^{1}$ \\ ARREBOLA, N. R. ${ }^{2}$ and TOLEDO, L. A. ${ }^{3}$ \\ ${ }^{1}$ Centro de Microscopia Eletrônica, Instituto de Biociências, Universidade do Estado de São Paulo, \\ Rubião Júnior, CEP 18608-000, Botucatu, SP, Brazil \\ ${ }^{2}$ Departamento de Histologia, Centro de Ciências Biológicas, Universidade Estadual de Londrina, \\ Londrina, PR, Brazil \\ ${ }^{3}$ Departamento de Morfologia, Instituto de Biociências, Universidade do Estado de São Paulo/UNESP, \\ Rubião Júnior, CEP 18608-000, Botucatu, SP, Brazil
}

Correspondence to: Sheila Michele Levy, Centro de Microscopia Eletrônica, Instituto de Biociências, Universidade do Estado de São Paulo, Rubião Júnior, CEP 18608-000, Botucatu, SP, Brazil, e-mail: sheilalevy @laser.com.br

Received February 28, 2003 - Accepted April 30, 2003 - Distributed August 31, 2004

(With 12 figures)

\begin{abstract}
The morphology of the midgut epithelium cells of Anticarsia gemmatalis (Hübner) larvae is described by light and transmission electron microscopy. The midgut of $A$. gemmatalis is the largest portion of the digestive tract, with three distinct regions: proximal, media and distal. Its wall is formed by pseudostratified columnar epithelial tissue having four cell types: columnar, goblet, regenerative, and endocrine cells. The columnar cells are numerous and long, with the apical portion showing many lengthy microvilli and the basal portion invaginations forming a basal labyrinth. The goblet cells have a large goblet-shaped central cavity delimited by cytoplasmic projections filled with mitochondria. The regenerative cells present electron-dense cytoplasm and few organelles. The endocrine cells are characterized by electron-dense secretory granules, usually concentrated in the cytoplasm basal region.
\end{abstract}

Key words: Lepidoptera, velvetbean caterpillar, morphology, ultrastructure, midgut.

\section{RESUMO}

\section{Intestino médio de larvas de Anticarsia gemmatalis (Hübner) (Lepidoptera: Noctuidae):} estudo das células epiteliais ao microscópio de luz e eletrônico

A morfologia das células epiteliais do intestino médio de larvas de Anticarsia gemmatalis (Hübner) é descrita em microscopia de luz e eletrônica de transmissão. O intestino médio de $A$. gemmatalis é a maior porção do trato digestivo, apresentando três regiões distintas: proximal, média e distal. Sua parede é formada por um tecido epitelial pseudo-estratificado colunar, com quatro tipos celulares: células colunares, caliciformes, regenerativas e endócrinas. As células colunares, observadas em maior quantidade, são altas, apresentam longas e numerosas microvilosidades na porção apical e na porção basal as invaginações da membrana formam o labirinto basal. As células caliciformes apresentam uma grande câmara central delimitada por projeções citoplasmáticas repletas de mitocôndrias no interior. As células regenerativas têm o citoplasma mais elétron-denso e com poucas organelas. As células endócrinas são caracterizadas pela presença de grânulos secretores bastante elétron-densos concentrados principalmente no citoplasma basal da célula.

Palavras-chave: Lepidoptera, lagarta-da-soja, morfologia, ultra-estrutura, intestino médio. 


\section{INTRODUCTION}

The digestive tract of insects is considered an effective physical and chemical barrier against potentially invasive pathogens that are ingested with food. The velvetbean caterpillar, A. gemmatalis (Lepidoptera: Noctuidae), is the major soybean crop pest in Brazil and has been biologically controlled by a nuclear polyhedrosis virus (AgMNPV). The infection starts when the caterpillar present in treated soybean tillage ingests the polyhedra that are dissolved and whose derived virions are released in the midgut lumen. These virions supposedly pass through the peritrophic membrane and fuse with the microvillar membrane of the midgut epithelial cells, initiating the replication cycle (Flipsen et al., 1995; Volkman, 1997). Although the biology of this pest has received a lot of attention, little is known about the larval internal morphology, especially the midgut, which plays a major role in food and insecticide absorption. This work provides a description by light and transmission electron microscopy of the epithelial cell types observed in the midgut of the A. gemmatalis noninfected larvae, aiming to improve the understanding of the morphophysiological mechanisms involved in the defense of this insect, when in contact with the AgMNPV.

\section{MATERIALS AND METHODS}

Anticarsia gemmatalis (Hübner) larvae were provided by the Laboratório Entomológico, Centro Nacional de Pesquisa da Soja (Embrapa Soja), Londrina, Paraná State, Brazil. The larvae were maintained in the laboratory with an artificial diet (Hoffmann-Campo et al., 1985) under controlled temperature $\left(25-27^{\circ} \mathrm{C}\right)$, photoperiod $(14 \mathrm{~h}$ light $/ 10$ $\mathrm{h}$ dark), and relative humidity $(80 \%)$.

Larvae of the 5th and 6th instars (12-16 days), after being rapidly rinsed in $70 \%$ alcohol, were immobilized in a freezer (5 $\mathrm{min}$ ) and dissected in Petri dishes containing paraffin under a stereomicroscope in insect saline solution (ISS - 1.80 $\mathrm{g}$ of $\mathrm{NaCl} ; 1.88 \mathrm{~g}$ of $\mathrm{KCl} ; 0.16 \mathrm{~g}$ of $\mathrm{CaCl}_{2} ; 0.004$ $\mathrm{g}$ of $\mathrm{NaHCO}_{3}$; distilled water-q.s.p. $100 \mathrm{ml}$ ).

For light microscope studies, the midgut was isolated and fixed in Bouin's solution or in the phosphate buffer $(0.1 \mathrm{M}, \mathrm{pH} 7.3)$ with glutaraldehyde $(2.5 \%)$ and paraformaldehyde (4.0\%) solutions. After dehydration in a graded ethanol series, the material was embedded in paraplast or in JB4 historesin and cut with glass knives in a rotary microtome. The sections were stained with hematoxylin-eosin, analyzed, and photographed with an Axiophot (Zeiss) photomicroscope. For electron microscopic studies, the midgut was fixed in a solution containing $2.5 \%$ glutaraldehyde and $4.0 \%$ paraformaldehyde in 0.1 M phosphate buffer ( $\mathrm{pH} 7.3$ ), postfixed in $1 \%$ osmium tetroxide solution in the same buffer, dehydrated in a graded acetone solution, and embedded in Araldite ${ }^{\circledR}$. Ultra-thin sections were stained with uranyl acetate and lead citrate, analyzed, and photographed with an EM-301 (Phillips).

\section{RESULTS}

The midgut wall of the A. gemmatalis consist of an acellular peritrophic membrane that delimits the midgut lumen in ectoperitrophic and endoperitrophic spaces, a pseudostratified columnar epithelial tissue with a brush border, a basement membrane, and muscular layers composed of bundles of inner circular and outer longitudinal muscles (Figs. 1-3).

The columnar cells are numerous and prismatic in shape with basophilic cytoplasm, which is sometimes vacuolated. Acidophilic brush border and some secretory vesicles are seen in the apical region (Figs. $2-4)$; in addition, cytoplasmatic portions can be released towards the ectoperitrophic space (Fig. 3).

Ultrastructurally, three distinct portions were recognized in this cell type, from apex to base: the apical portion, rich in long microvilli and large quantities of mitochondria (Figs. 5-6); the middle portion, characterized by large amounts of rough endoplasmic reticulum, developed Golgi complex, and some mitochondria (Fig. 7); and the basal portion, with mitochondria frequently associated with basal plasma membrane infolds forming the basal labyrinth (Fig. 8).

The goblet cells show a large basal region, acidophilic cytoplasm, and basal nucleus with loose clustered chromatin (Fig. 2). This cell type presents a large goblet-shaped cavity (Figs. 2-5 and 9-10) delimited by cytoplasmic projections filled with mitochondria (Figs. 5, 9-10). The apex shows smaller and thinner projections, with no mitochondria, that are organized in the form of a valve type that almost closes the cavity (Fig. 5). The cytoplasm is scarce, with Golgi complex, mitochondria, and a poorly developed rough endoplasmic reticulum (Fig. 9). In the basal region, a basal labyrinth is also seen, although less developed than the columnar cells (Figs. 9-10). 

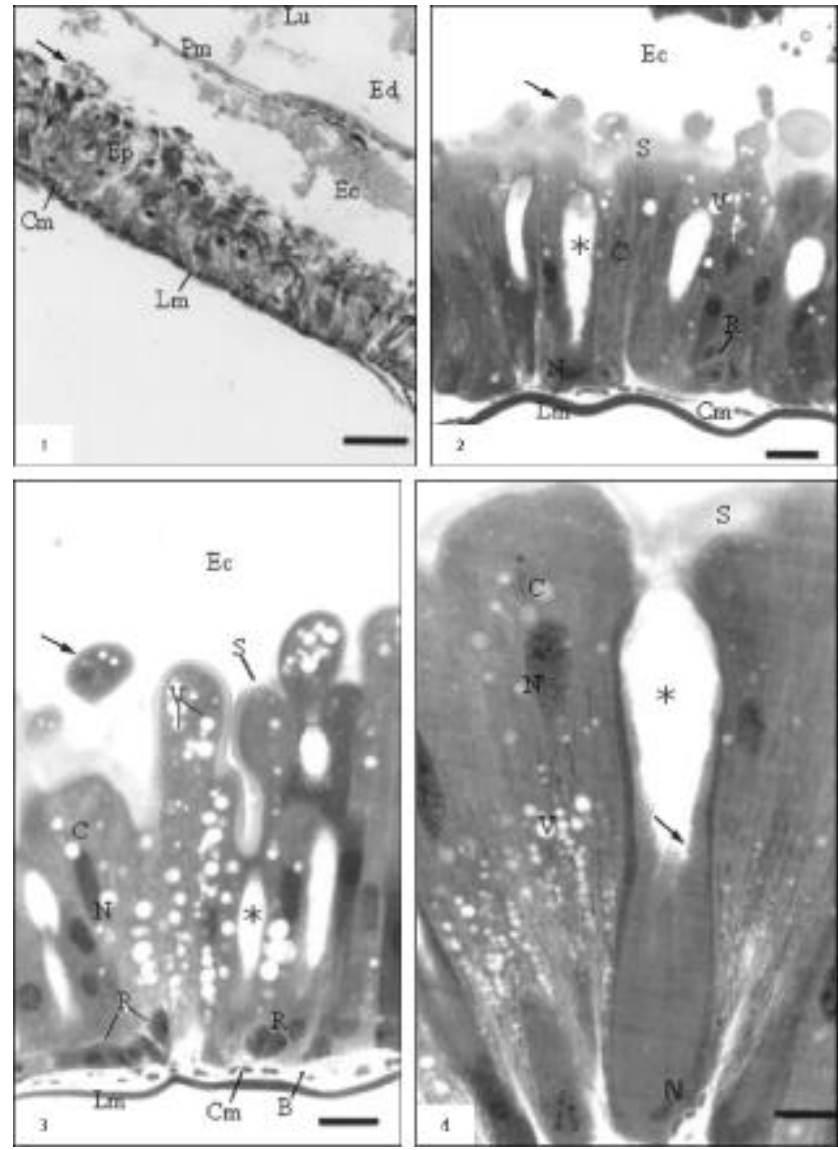

Fig. 1 - General aspects of the midgut: lumen (Lu); peritrophic membrane (Pm); endoperitrophic (Ed) and ectoperitrophic (Ec) spaces; apical vesicles (arrow); epithelium (Ep); circular $(\mathrm{Cm})$ and longitudinal $(\mathrm{Lm})$ muscles (bar: $50 \mu \mathrm{m})$. Fig. 2 - Epithelium showing columnar cells $(\mathrm{C})$; apical vesicles (arrow) striated border (S); goblet cell with goblet-shaped cavity $(*)$ and regenerative cells $(\mathrm{R})$. Ectoperitrophic space $(\mathrm{Ec})$; cytoplasmatic vacuoles $(\mathrm{V})$; nucleus $(\mathrm{N})$; circular $(\mathrm{Cm})$ and longitudinal (Lm) muscles (bar: $25 \mu \mathrm{m}$ ). Fig. 3 - Columnar cells (C) showing cytoplasmatic portions (arrow), striated border (S) and cytoplasmatic vacuoles (V); goblet-shaped cavity $(*)$; regenerative cells $(\mathrm{R})$. Ectoperitrophic space $(\mathrm{Ec})$; nucleus $(\mathrm{N})$; basal lamina $(\mathrm{B})$; circular $(\mathrm{Cm})$ and longitudinal $(\mathrm{Lm})$ muscles (bar: $25 \mu \mathrm{m}$ ). Fig. 4 - Goblet cell: goblet-shaped cavity $(*)$ ), cytoplasmic projections (arrow); nucleus (N). Columnar cell (C); striated border (S); vacuoles (V); nucleus (N) (bar: $10 \mu \mathrm{m})$.

The regenerative cells were found singly, paired, or in groups (also called nidi) in the basal region of the epithelium. They are round or oval in shape, with strongly basophilic cytoplasm (Figs. 2-3) containing a few rough endoplasmic reticulum and some mitochondria (Fig. 10).

The endocrine cells, rarely found along the midgut epithelium, are often located at the base, being able to extend up to the midgut lumen. They are conical in shape, with clear cytoplasm, with great amounts of granules containing electron-dense material, mainly in the basal region (Fig. 11). Two distinct types of granules are observed, mainly near the basal lamina: solid granules entirely filled by a dense matrix, and haloed granules having a clear space between the membrane and the dense matrix core (Fig. 12). Large quantities of vacuoles with membranous material are observed in the apex region, Golgi complex, mitochondria of different sizes and shapes, free ribosomes, and rough endoplasmic reticulum (Figs. 11-12). Stocks of glycogen and myelin figures are also observed. 

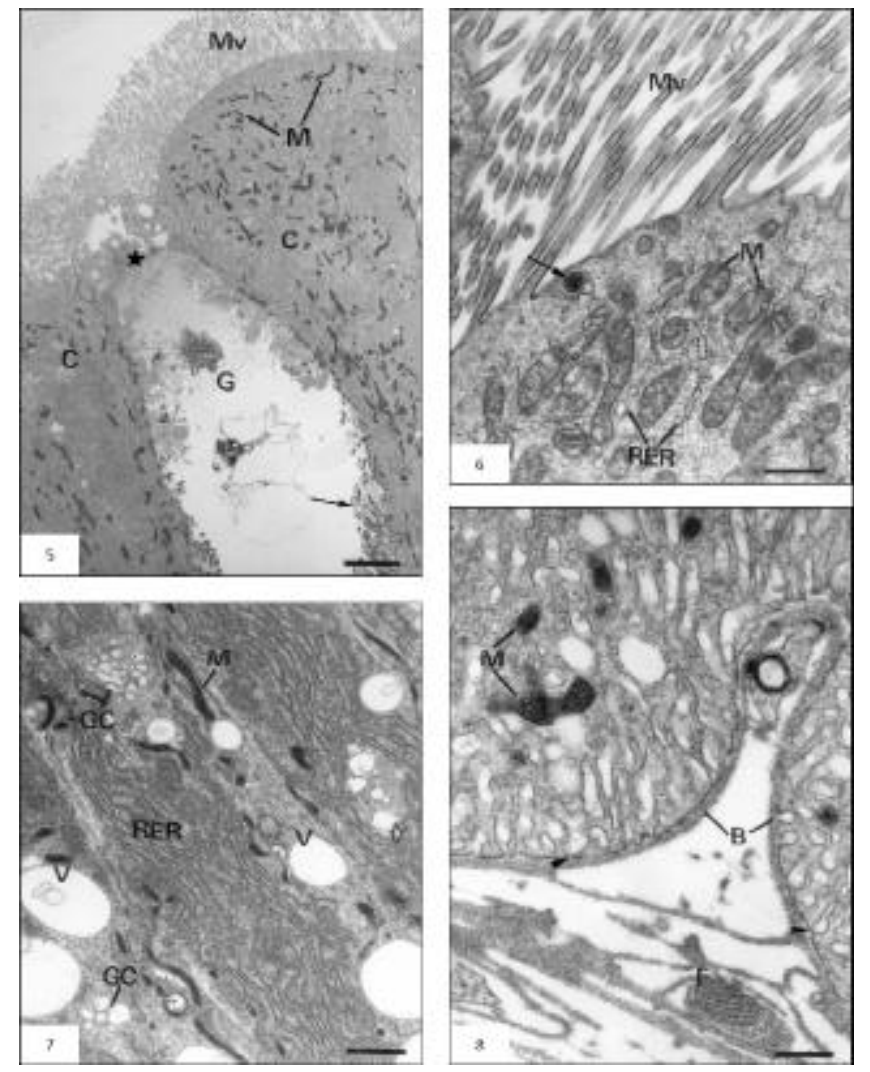

Fig. 5 - Ultrastructural aspects of columnar cell (C) with microvilli (Mv) and mitochondria (M). Goblet cell (G) with the gobletshaped cavity delimited by lateral cytoplasmic projections (arrow) and apical projections forming a valve type ( $\star$ ) (bar: $3 \mu \mathrm{m})$. Figs. 6-8 - Columnar cell (C): Details of apical portion - microvilli (Mv), mitochondria (M), rough endoplasmic reticulum (RER) and vesicles with electron-dense (arrow) (bar: $0.4 \mu \mathrm{m}$ ); middle portion - rough endoplasmic reticulum (RER), dilated Golgi complex (GC), electron-lucent vacuoles $(\mathrm{V})$, mitochondria $(\mathrm{M})($ bar: $0.8 \mu \mathrm{m})$; and basal portion - mitochondria (M) associated with basal labyrinth (arrowheads). Basal lamina (B); muscular fiber (F) (bar: $0.5 \mu \mathrm{m})$.

\section{DISCUSSION}

The columnar cells, which have several names, e.g., digestive cells, principal cells, absorptive cells, and enterocytes, are predominant along the epithelium of the midgut wall of $A$. gemmatalis larvae and show similar morphological aspects to other Lepidoptera species described by authors such as Santos et al. (1984), Richards \& Davies (1994), and Cristofoletti et al. (2001).

The characterization of three distinct portions in this cell type (apical, middle, and basal portions) shows cellular compartmentalization that is related with the several and distinct functions of columnar cells. The presence of numerous and long microvilli and large quantities of mitochondria in the cell apex (apical portion), the well-developed rough endoplasmic reticulum and Golgi complex (middle portion), and the basal plasma membrane infoldings with associated mitochondria (basal portion) indicate that the columnar cells serve in nutrient absorption; protein synthesis, mainly related to digestive enzyme production; and ion and water transport, according to Richards \& Davies (1994) and Jordão et al. (1999). Structural features of the basal portion may constitute an extracellular compartment that not only allows restricted access to the hemolymph, but in which the cell can concentrate solutes, thus creating an osmotic gradient between it and the lumen, which might promote water absorption (Santos et al., 1984).

The presence of secretory vesicles and cytoplasmic extrusions, which are seen in the cell apex in A. gemmatalis, are also described in Hyalophora cecropia (Anderson \& Harvey, 1966), Ephestia kühniella (Smith et al., 1969), and Apis mellifera (Jimenez \& Gilliam, 1990). 

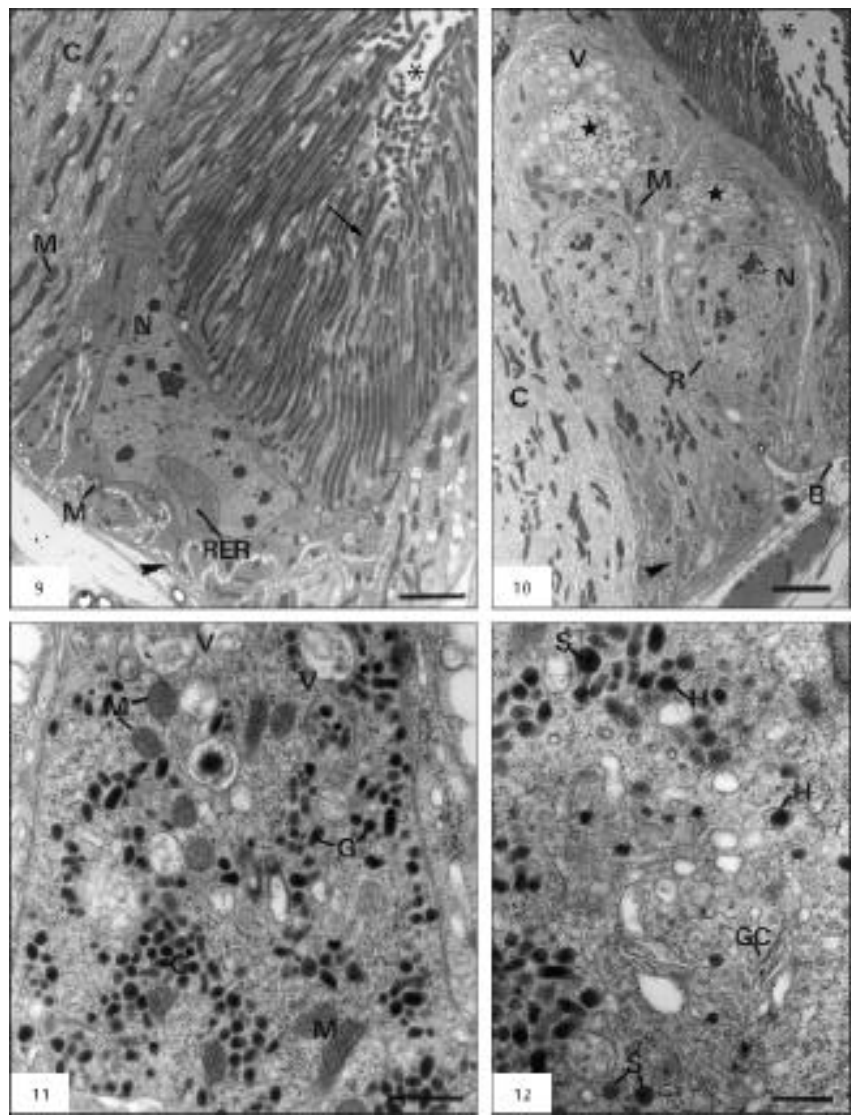

Fig. 9 - Goblet cell showing goblet-shaped cavity (*), lateral cytoplasmic projections (arrow), mitochondria (M), rough endoplasmic reticulum (RER), basal labyrinth (arrowheads) and nucleus (N). Columnar cell (C) (bar: $2 \mu \mathrm{m})$. Fig. 10 - The regenerative cells $(\mathrm{R})$ with central nucleus $(\mathrm{N})$, mitochondria $(\mathrm{M})$, electron-lucent vacuoles $(\mathrm{V})$ and stocks of glycogen ( $\star$ ). Columnar cell (C); goblet cell with goblet-shaped cavity ( $*$ ); basal labyrinth (arrowheads); basal lamina (B) (bar: $1 \mu \mathrm{m}$ ). Fig. 11 — Endocrine cell containing dark granules $(\mathrm{G})$, vacuoles with membranous material (V) and mitochondria (M) (bar: $0.25 \mu \mathrm{m})$. Fig. 12 — Detail of two distinct types of dark granules near to Golgi complex (GC): the solid (S) and the haloed (H) granules (bar: $0.25 \mu \mathrm{m})$.

These authors have suggested that the cytoplasmic loss phenomenon is probably correlated with cell degeneration resulting from epithelial renewal, while Terra \& Ferreira (1994) and Cristofoletti et al. (2001) believe that these features are related to high secretory enzymatic activity.

The goblet cells described in the epithelial midgut of $A$. gemmatalis larvae are similar to those found in other Lepidoptera species. They present a typical goblet-shaped cavity, called "goblet chamber", formed by an apical infolding of the plasma membrane. Into this cavity extend cell surface basal and lateral projections, similar to microvilli but filled with mitochondria. Apical projections form a valve type, which would permit the confluence of the cavity with the lumen, controlling fluid movements between them (for revision,
Chapman 1998). According to Billingsley \& Lehane (1996), the presence of mitochondria inside the projections is a unique characteristic in arthropods, is related to active transport of potassium ions from the hemolymph to midgut lumen, and calcium ions from adjacent columnar cells (Klein et al., 1991; Koch \& Moffett, 1995; Moffett et al., 1995). The presence of these cell types can explain the high $\mathrm{pH}(8.0-12.0)$ in the midgut of Lepidoptera and Ephemeroptera (Dow, 1984, apud Terra, 1988).

Similar morphological aspects of regenerative cells in A. gemmatalis are also reported by Billingsley \& Lehane (1996). It is known that epithelial cells of the midgut undergo desquamation during digestion and new cells renew them by mitotic activity in regenerative cells. This cellular renewal happens due 
to the growing digestive tube at each ecdyse as well as injured cell replacement; it also helps defense mechanisms against pathogens infecting these cells (Chiang et al., 1986). The fourth cell type found, the endocrine cells, presented different types based on their location, shape, and on the morphology and electron-density of their granules (Raes \& Verbeke, 1994; Billingsley \& Lehane, 1996; Jordão et al., 1999: Cristofoletti et al., 2001). These cells are functionally similar to neurosecretory cells of the vertebrate gut, synthesizing a large variety of polypeptide hormones which act in regenerative cell differentiations and the control of specific digestive enzyme secretion after feeding (Martoja \& Ballan-Dufrançais, 1984; Billingsley \& Lehane, 1996). We intend to perform further studies to better characterize this cell type.

In conclusion, the cells types found in the midgut epithelium of $A$. gemmatalis larvae, though similar to those described for the Lepidoptera species, require attention in morpho-physiologic studies being developed which aim to increase the effectiveness of techniques used in the control, principally biological, of this pest.

Acknowledgements - We thank the Centro Nacional de Pesquisa da Soja (Embrapa Soja), Londrina, Paraná State, Brazil, especially Dr. Flávio Moscardi, for supplying A. gemmatalis larvae, and the Centro de Microscopia Eletrônica (CME), principally Nivalde Antônio Basso and Maria Helena Moreno, for help in processing and analyzing material used. This work was supported by the Conselho Nacional de Desenvolvimento Científico e Tecnológico (CNPq) and Fundação de Amparo à Pesquisa do Estado de São Paulo (FAPESP).

\section{REFERENCES}

ANDERSON, E. \& HARVEY, W. R., 1966, Active transport by the Cecropia midgut: II. Fine structure of the midgut epithelium. J. Cell Biol., 31: 107-134.

BILLINGSLEY, P. F. \& LEHANE, M. J., 1996, Structure and ultrastructure of the insect midgut, pp. 3-30. In: M. J. Lehane \& P. F. Billingsley (eds.), Biology of the Insect midgut. Chapman \& Hall, London.

CHAPMAN, R. F., 1998, The insects: structure and function. 4. ed. Havard University Press, Cambridge.

CHIANG, A. S., YEN, D. F. \& PENG, W. K., 1986, Defense reaction of midgut epithelial cells in the rice moth larva (Corcyra cephalonica) infected with Bacillus thuringiensis. J. Invert. Pathol., 47: 333-339.

CRISTOFOLETTI, P. T., RIBEIRO, A. F. \& TERRA, W. R., 2001, Apocrine secretion of amylase and exocytosis of trypsin along the midgut of Tenebrio molitor larvae. J. Insect Physiol., 47: 143-155.
FLIPSEN, J. T. M., MARTENS, J. W. M., VAN OERS, M. M., VLAK, J. M. \& VAN LENT, W. M., 1995, Passage of Autographa californica nuclear polyhedrosis virus through the midgut epithelium of Spodoptera exigua larvae. Virol., 208: 328-335.

HOFFMANN-CAMPO, C. B. H., OLIVEIRA, E. B. \& MOSCARDI, F., 1985, Criação massal da lagarta-da-soja (Anticarsia gemmatalis). EMBRAPA/CNPSo, Londrina.

JIMENEZ, D. R. \& GILLIAM, M., 1990, Ultrastructure of the ventriculus of the honey bee, Apis mellifera (L.): cytochemical localization of acid phosphatase, alkaline phosphatase, and nonspecific esterase. Cell Tissue Res., 261: 431-443.

JORDÃO, B. P., CAPELLA, A. N., TERRA, W. R., RIBEIRO, A. F. \& FERREIRA, C., 1999, Nature of the anchors of membrane-bound aminopeptidase, amylase, and trypsin and secretory mechanisms in Spodoptera frugiperda (Lepidoptera) midgut cells. J. Insect Physiol., 45: 29-37.

KLEIN, U., LÖFFELMANN, G. \& WIECZOREC, H., 1991, The midgut as a model system for insect $\mathrm{K}+$ transporting epithelia: immunocytochemical localization of a vacuolartype H+ pump. J. Exp. Biol., 161: 61-75.

KOCH, A. \& MOFFETT, D. F., 1995, Electrophysiology of K+ transport by midgut epithelium of lepidopteran insect larvae. IV. A multicompartment model accounts for tetramethylammonium entry into goblet cavities. J. Exp. Biol., 198 2115-2125.

MARTOJA, R. \& BALLAN-DUFRANÇAIS, C., 1984, The ultrastructure of the digestive and excretory organs, 2, pp. 119-261. In: R. C. King \& H. Akai (eds.), Insect ultrastructure. Plenum Press, New York.

MOFFETT, D. F., KOCH, A. \& WOODS, R., 1995, Electrophysiology of $\mathrm{K}+$ transport by epithelium of lepidopteran insect larvae. III. Goblet valve patency. J. Exp. Biol., 198: 2103-2113.

RAES, H. \& VERBEKE, M., 1994, Light and electron microscopical study of two types of endocrines cell in the midgut of the adult worker honeybee (Apis mellifera). Tissue \& Cell., 26: 223-230.

RICHARDS, O. W. \& DAVIES, R. G., 1994, The alimentary canal, nutrition and digestion, pp. 192-208. In: O. W. Richards \& R. G. Davies (eds.), IMMS' General Textbook of Entomology, 10. ed., Chapman \& Hall, London.

SANTOS, C. D., RIBEIRO, A. F., FERREIRA, C. \& TERRA, W. R., 1984, The larval midgut of cassava hornworm (Erinnyis ello): ultrastructure, fluid flux and the secretory activity in relation to the organization of digestion. Cell Tissue Res., 237: 565-574.

SMITH, D. S., COMPHER, K., JANNERS, M., LIPTON, C. \& WITTLE, L. W., 1969, Cellular organization and ferritin uptake in the mid-gut epithelium of a moth Ephestia kühniella. J. Morphol., 127: 41-72.

TERRA, W. R., 1988, Physiology and biochemistry of insect digestion: an evolutionary perspective. Braz. J. Med. Biol. Res., 21: 675-734.

TERRA, W. R. \& FERREIRA, C., 1994, Insect digestive enzymes: properties, compartmentalization and function. Comp. Biochem. Physiol., 109B: 1-62.

VOLKMAN, L. E., 1997, Nucleopolyhedrovirus interations with their insect hosts. Adv Virus Res., 48: 313-348. 